\title{
Ethnic Pedagogy as an Integrative, Developing Branch of Pedagogy
}

\author{
Kozhakhmetova Klara* \\ Correspondence Author, Kazakh National University after al Farabi, Faculty of Philosophy \& Politology, \\ Department of General and Ethnic Pedagogy, Dr of Pedagogy, Professor \\ Email: kl.jantore@yandex.ru \\ Ortayev Baktiyar \\ International Kazakh-Turkish University after Yassaui, Turkestan City \\ Faculty of Humanity Sciences, Department of Educational Technology, \\ Dr. of Pedagogy, Docent, Head of the Department "Educational Technology" Email: ortaevbaktiyar@mail.ru
}

Kaliyeva Sandygul

Departmental Organization of the Ministry of Education, Republican Scientific and Practical Centre "Tutorial," Candidate of Pedagogy, leading expert, Astana city Email: candigold-1961@mail.ru

Utaliyeva Raikhan

Atyrau city, Atyrau State University. H. Dosmukhamedov, Faculty of Economics and Law, Department of Economic Theory and Public Administration, PhD Candidate of Pedagogical Sciences, Head of the Department of Economic Theory and Public Administration, utalieva68@mail.ru

\section{Jonissova Gulzhiyan}

West Kazakhstan Engineering Humanitarian University, Faculty of Social Sciences and Humanities, Department of Pedagogy and Psychology, Ph.D., Associate Professor of West Kazakhstan Engineering-Humanitarian University Email: Dzhonisova@mail.ru

\section{Doi:10.5901/mjss.2015.v6n1s1p612}

\section{Abstract}

The article presents the author's concept of the Kazakh ethno-pedagogy, developed on the basis of many years research. Devoted to disclosing theoretical and methodological foundations of ethno-pedagogy and Kazakh ethno-pedagogy, substantiation of its scientific status and place in the system of the human sciences. In the article, ethno-pedagogy is seen as an integrative branch of pedagogy, which was formed in the womb of pedagogy, at the junction of ethnic psychology, ethnophilosophy, ethnology, and ethnoculturology, which has its object and subject of research and conceptual and terminological apparatus. The introductory part of the article provides a brief analysis of the historical-pedagogical and scientific-theoretical assumptions of ethno-pedagogical ideas in Kazakhstan. The final part of the article presents ethno-pedagogical development tendencies, prospects of research, and ethno-pedagogy as a science and academic discipline.

Keywords: ethno-pedagogy, ethnic upbringing, folk pedagogy, folk knowledge, ethno-pedagogics education, ethno-pedagogics culture

\section{Introduction}

Ongoing changes that cover all spheres of social economic life of the country are accompanied by complex processes of change in people's minds, require increments of fundamental and universal knowledge, and must be realized through the education system. In this connection, particular actuality has gained the idea as set out in the Concept of Humanitarian Education in the Republic of Kazakhstan (1994): "Since previous education system in the country it was oriented mainly on samples of past scientific knowledge, without proper consideration of human nature and its vital interests and needs, the real values of the culture that led to the unification of education and following unit postulates and canons, it is 
necessary to critically examine given orientation of pedagogy and, saving all value, reform it according to the ethnic necessity by trained audience." The document rightly points out that large-scale reform of the education system can not be effective without serious scientific research and specific recommendations in the area of academic discipline such as ethno-pedagogy, which served as a powerful stimulus for the development of ethno-pedagogical research in the country.

Work analyses of researchers in Kazakhstan and CIS on ethno-pedagogy allowed to single out a number of issues of problematic methodological character: firstly, an undeveloped unified point of view regarding what is meant by ethnopedagogy; this concept is considered by researchers as: a) science at the junction ethnography, folklore studies, pedagogy (G.N. Volkov and etc.); b) an interdisciplinary branch of knowledge at the intersection of ethnography, sociology and pedagogy (Y.V. Bromley, Shtrobakh and etc.); C) pedagogical discipline (E.L. Khristova and etc.); integral part of pedagogical science, its basic components (G.N. Volkov, G.M. Khrapchenkov, S.K. Kalyev, S.A. Uzakbaeva and etc.), and e) branch of scientific pedagogy (C.B. Zharykbaev). Secondly, it is often identified by researchers to be an object and subject of ethno-pedagogy; thirdly, it remains a controversial issues in the relationship between: a) pedagogy and ethno-pedagogy; b) ethno-pedagogy and folk pedagogy; c) ethno-pedagogy, folk pedagogy and social pedagogy; fourthly, it is an under-researched question of the ethno-pedagogy place in the system of pedagogical knowledge.

The above-mentioned problems appeared to be an overdue expression of the contradiction between the necessity to justification status of the Kazakh ethno-pedagogy as an integral part of the pedagogical science and underdevelopment of its theoretical and methodological foundations, practical necessity in ethno-pedagogical knowledge, and the lack of a conceptual approach to the definition of the essence of ethno-pedagogical education.

Perceptions and theoretical understanding of the identified problems allowed the author of the present work to identify the methodological foundations of Kazakh ethno-pedagogy; substantiate interconnection of pedagogy as common, ethno-pedagogy as special, Kazakh ethno-pedagogy as unit; develop the structural and logical model of the Kazakh ethno-pedagogy; discover the essence, content, forms, methods and means of ethnic Kazakhs upbringing; develop the concept of ethno-pedagogical education of high school students.

The purpose of this article is to introduce with author's conception of justification essence of ethno-pedagogy as integrative branch of pedagogical knowledge, represented by its structural and logical model, to show tendencies and development prospects of ethno-pedagogy and ethno-pedagogical research in the Republic of Kazakhstan.

Relevance of such research lies in the fact that globalization increases the need for preservation of the identity of each ethnic community, but ethno-pedagogy, as the "science of national salvation" and the original nucleus of comparative pedagogy, will prevent cultural assimilation, thus contributing to the "dialogue of cultures," preserving the uniqueness.

The research methodology relies on a system, activity, anthropological, axiological, structural and logical, structural and analytical, ethno-cultural, ethnographic, and ethno-pedagogical approaches.

\section{Ethno-pedagogy as a science}

Ethno-pedagogy - comparatively young branch of scientific-pedagogical knowledge.

The first time the term "ethnopedagogy" was introduced into scholarly circulation was by famous scientist, Gennady Nikandrovich Volkov in 1974. During this period of its development, there has been significant positive progress.

The theoretical origins of ethnic pedagogy takes in classical pedagogy, which is the most outstanding representative of J.A. Comenius. The native word according to J. Comenius, was the beginning of all beginnings. He saw one of the ways of raising national consciousness of the people and development of the national culture. The idea of J.A. Comenius about a School of the native language found its further creative development in the works of the classic Russian pedagogy K.D. Ushinsky, who in his pedagogical system embodied the main features of Russian classical pedagogy, justified the principle of nationality, which is characterized by the desire to maintain national "I"dentity; eligibility: the unity of the people (Lordkipanidze DO, 1954) [1, p. 160]. Precisely in this true sense, the principle of nationality, not only has not lost its relevance, but it requires a creative renaissance.

Samples of the scientific approach to national traditions also left other members of Russian pedagogy, including N.K. Krupskaya and A.S. Makarenko. Later, based on their ideas and experience, V.A. Suhomlinsky came close to the scientific basis of the nationality principle. Problems of National Education, and the "science of education" deeply troubled scientist-pedagogue, philosopher, publicist S.I. Hesse. According to his deep conviction that "pedagogy is nothing else than the recognition of education... it is - the science about art of activity... is not about what is, and what ought to be, not investigating what is, and what we should do." In this sense, the Kazakh pedagogy can also be attributed to the "science of proper" about "how we should act," because the means and methods of upbringing in the Kazakh ethno-pedagogy 
based on upbringing traditions, customs, rites and rituals play a normative and regulatory. In the study of history, culture, way of life and traditions of the people important meaning has source base. Names of researchers-ethnographers, folklorists A.I. Levshin, V.V. Radloff, A. Divaev, N.L. Zeland widely known to pedagogues-historians, psychologists, cultural scientists.

The ideas of nationality principle run throughout all of the Kazakh educators, pedagogues and public-political figures as A. Kunanbaev, Sh. Ualikhanov, Y. Altynsarin, M. Zhumabayev, Zh. Aimauytov, M. Dulatov,H. Dosmukhamedov. An analysis showed that Ethno-pedagogical views and ideas, embodied in the principle of nationality, without interruption passed from generation to generation. Pedagogues of all generations, paid attention to native language, the study of history, geography of his native land, paying attention to maintaining the identity of the Kazakh ethnic group. As studies show, Kazakh scientists historians, anthropologists, philosophers, and pedagogues (S.A. Assanova, B.M. Suzhikova, K. Zhukesh, V.G. Hrapchenkova and etc.) up to 20 years of XX century in the development of ethno-pedagogical ideas was the "top of the parabola," because this period began to develop Kazakh school. Upbringing was realized by people as task, necessary not only for self-keeping, but also for improvement of living conditions. So, through education was provided the continuity of generations. However, from October 1917 to 1991, the ethnic upbringing has undergone a lot of "heavy" trials, retaining only some items. The stronghold of ethnic upbringing, though very exhausted, remained all these years in the Kazakh family. Research in the field of ethno-pedagogy was not conducted. Only in the last 70 years, appeared individual works on the issues of ethnic upbringing, though in essence they were more devoted to the problems of the ethnic revival upbringing: the works of A.H. Muhambaeva, I. Orshibekova.

The emergence of independent Kazakhstan in 1991 created the preconditions for the revival of a truly national Kazakh schools, they were opened opportunities for the research and objective analysis and evaluation of historical and educational facts for the development of the Kazakh ethnic pedagogy. The real state of the Kazakh ethnic upbringing today leaves much to be desired, although not in any way diminish the importance of those achievements, which in recent years have taken place.

When determining the essence of Kazakh ethno-pedagogy we as a starting study were based on the idea of T.I. Ogorodnikov that ethno-pedagogy has emerged as a "new area, linking pedagogy with ethnography and folklore" (Volkov G.N., 1974) [2, p. 6]. Ethno-pedagogy - an integral part of pedagogy, and as parts of the whole are inherent pedagogical features: the laws, principles of pedagogy theory that are methodological in relation to the ethno-pedagogy, but ethnopedagogy has its own specificity, namely: it explores a specific aspect - ethno-pedagogical. But as ethno-pedagogy - the area that connects pedagogy with other sciences that have close to Ethno-pedagogical object, we have decided to further consider, what are the links between Ethno-pedagogy and ethnography, and Ethno-pedagogy ethno-philosophy, Ethno-pedagogy culture of philosophy. In this issue we turned to research B. Kedrov, V.I. Zhuravlev, to reveal the essence, specifics of the Kazakh ethno-pedagogy. We examined many of its definitions in the works of well-known scientists (G.N.Volkov, E.L.Hristova, M.I. Stelmahovich, A.E. Izmailov, A. Sh. Gashimov, S.K. Kaliev, K.B. Zharykbaev, S.A. Uzakbaeva, G.M. Khrapchenkov, G. Filonov, V.A. Sukhomlinsky and etc.), which made it possible to identify the component structure of the Kazakh ethno-pedagogy, its structure, function, relationship with pedagogy, with folk and social pedagogy and to do following conclusion:

Pedagogy - the total, its laws operate to the area of ethnopedagogy;

Ethnopedagogy-especial, i.e., in pedagogy singles out ethnic specific aspect, characteristic of all ethnic groups, ethnic group forms;

Kazakh ethnopedagogy —it is the individual, i.e., here the researcher sees something specific, which was formed by the uniqueness of ethnic culture, expressed in the language, traditions, customs, traditions and religion. At the expense of peculiar ethnic worldview that emerged historically influenced by environmental conditions, life, business, psychology, ethnic Kazakhs, which finds its expression in his character, national feelings, the national consciousness. All of them find their point of contact in pedagogy, which plays an integrative and regulatory role, "placing" all of these types of knowledge in the niches components.

What is the system component integration? In our opinion, this is the Kazakh ethnic upbringing, i.e., Kazakh ethnopedagogy subject. All this underlines the specificity of Kazakh ethno-pedagogy: being part of pedagogy, it is at the same time has its own unique features that give it a stand-alone nature, unique. Kazakh ethnopedagogy as a branch of pedagogical knowledge, was formed on the intersection of education and Ethnography (ethnology); this is the area of pedagogy, which explores the ethnic aspect of upbringing and joins in connection with this pedagogy with ethnology, ethnography called theoretical, as opposed to descriptive ethnography). At the same time, ethnopedagogy-a component that is an integral part of the spiritual ethnic culture. Thus, in this area they are focused on important blocks of ethnopedagogical knowledge about ethnosophy (folklore, wisdom) socionormative cognitive culture, the culture of life support, tradition, religion, language, ethnic and social roles, etc. 
Ethnopedagogy, an integral part of pedagogy, has a problem, a subject, and the result. Pedagogical, although to achieve their goals, ethnopedagogy as an integral branch of knowledge uses components of ethnic culture as a specific means upbringing activities. Thus, there is a pedagogical essence of ethnopedagogy. As an integral part of the pedagogical science and its branch Kazakh ethnopedagogy, the main element around which is integration. As an integral part of the pedagogical science and its branch - Kazakh ethnopedagogy, the main element around which is integration. Combining in its composition ethnology, ethnic psychology, ethnic culture, etnophilosophy, it has become an integrative branch of knowledge. In this regard, the methodological framework of Kazakh ethnopedagogy constitute the basic methodological and theoretical positions these sciences with special priority and guiding role of pedagogy.

In this regard to appropriate following gradation: pedagogy - general, ethnopedagogy - especially Kazakh ethnopedagogy - the individual, that isstudying pedagogy, we are introduced to the laws, principles, methods of teaching and upbringing that have a universal character, studying ethnopedagogy we particularize pedagogical knowledge of the ethnic specificity. For "as it is impossible to live on the model of other people... just can not be brought up by someone else's system, no matter how slender she is well thought out and..." (Ushinsky K.D, 1988) [3, p.165]. In fact, every nation has its own unique system of bringing up, and this specificity associated with mental stock, language, national character, national identity, customs and traditions, religion Kazakhs - that is, a single, specific characteristic of the Kazakh ethnic group, explores the Kazakh-ethnopedagogy

Ethnopedagogy has a certain degree of independence due to the composition of its components. "Obeying the whole, the system - writes V. Afanasiev, - components have relative independence, a certain degree of freedom. The relative independence of the parts seen in the fact that each of them carries a certain time its specific, only her inherent function" (V.G. Afanasyev, 1981) [4, p.95]. The independence of ethnopedagogy confirmed by the fact that she has developed an inherent subject of study. After all, as you know, any branch of human knowledge consists in science only when clearly enough to isolate and specify the specific, peculiar only to her subject of study. But as "systemically study, as noted V.N.Sadovsky, a description of the elements of the analyzed object is carried out not by itself, but only in connection with and in accordance with their " place " as a whole" (Sadovsky V.N, 1983) [ 5, p. 93], we believe that to justify ethnopedagogy place in the teaching of science and its relationship to other sciences, first of all, necessary to the specification of relations ethnopedagogy Interscience, its structure, the types of bonds within the teaching of science, between the teaching disciplines, for "exposing" all these communications, we will identify the specific components of the system that will allow us to clearly see what is the place of ethnopedagogy in this whole system of bonds.

The study of the components included in the ethnopedagogy confirms that ethnopedagogy, being part of pedagogy, has specific properties that require a slightly different approach to the study of their specificity. That is on ethnopedagogy as an integral part of pedagogy spreads activity of laws and principles. However, in an area where there was a "layering" and formed an integral domain, then the knowledge in this area are ethnic specificity, i.e., reflect the ethnic dimension as a pedagogy, as cultural problem. Because the docking area is the object area of ethnopedagogy, ethnic ethnicity face life: for ethnopedagogy - developing ethnopedagogical reality, for ethno - ethnic characteristics of the psyche of people, ethnic identity, character, stereotypes, and for ethnophilosophy - folk wisdom, common sense of the people, and for Ethnology - ethnicity and relationships with their peers, and for ethnic culture - the culture of this ethnic group.

It should be noted that each of the disciplines considers an aspect of it: in this case, ethnopedagogy - the specific ethnic upbringing. As shown in the diagram, these science "butted" to each other in the subject area, form a branch of knowledge - ethnopedagogy, which has basis - pedagogy, therefore, the essence - pedagogical.

The relationship between ethnology and pedagogy - according to the object - the vital activity of the ethnic group. Since the subject of Ethnology - the theory of ethnicity, for ethnopedagogy - ethnos theory - the basis of its terminological apparatus that determines the essence of the ethnic aspect ethnopedagogy.

The relationship between ethnic culture and ethnopedagogy. Ethnopedagogy - an integral part of the spiritual culture of the people, therefore, ethnopedagogy's resources are defined by ethnic culture.

The relationship between ethnopedagogy and ethnosophy. The content of ethnopedagogy also provides folk wisdom, folk knowledge that feeds it as a source.

The relationship between ethnopedagogy and ethnopsychology. Relation on research of problems the formation of national identity, national character, national feelings, etc. In this regard, the need for a thorough and in-depth study and development of ethno-psychological foundations ethnopedagogy.

The relationship between philosophy and of Kazakh ethnopedagogy. Kazakh philosophy is a worldview that defines essence of Kazakh attitude. In this sense, it affects the formation of the ideological orientation of Kazakh content ethnopedagogy.

Thus, the types of relationships between these disciplines is much deeper than it seems at first glance, there is a 
link within an object, that is, at the level of integration. As noted in this regard I.M. Cantor, "objective basis for integration is the unity of the world, a universal connection and interdependence of objects and phenomena, the historical continuity of the forms of matter and motion, known isomorphism structures qualitatively heterogeneous systems" ( I.M. Cantor, 1980) [ 6, p.291 ]. As already mentioned, due to the integrative bonds formed branch of knowledge - Kazakh pedagogy, but it is leading - pedagogy. Only a complex interaction of science, which in the opinion of Kedrov, "as a rule, any one science is serving as lead " ( Cedars BM, 1985) [ 7, p. 21], makes it possible to discover the objective laws of its development and operation. The analysis allowed us to give the following definition: Kazakh pedagogy - an integral part of teaching science, its branch, formed in the womb of pedagogy at the intersection of ethnic psychology, ethnography, ethnophilosophy, ethnoculturology, the subject of which is the system of the Kazakh ethnic education, carried out continuously throughout the life of the family and in institutions of education (see Table 1).

Table 1: Structural and logical model of Kazakh ethno-pedagogy (Kozhakhmetova K.Zh., 1998)

\begin{tabular}{|c|c|c|c|}
\hline \multirow[t]{2}{*}{\begin{tabular}{|l} 
Sections of \\
science \\
components
\end{tabular}} & \multicolumn{3}{|c|}{$\begin{array}{l}\text { Kazakh pedagogy - an integral part of the pedagogical science, its branch, formed in the bosom of pedagogy at the junction of the Kazakh } \\
\text { philosophy, of ethnic psychology, ethnography, ethnoculturology, the subject of which are features of the Kazakh ethnic upbringing, carried } \\
\text { out continuously throughout the whole of human life in the family and institutions of education system. }\end{array}$} \\
\hline & \begin{tabular}{|l}
$\begin{array}{l}\text { Methodology of ethnic } \\
\text { pedagogy }\end{array}$ \\
\end{tabular} & Theory of ethnopedagogy & Practice \\
\hline \begin{tabular}{|l|} 
Aims and \\
objectives
\end{tabular} & \begin{tabular}{|l|} 
•identification "knowledge \\
about cognition" of the Kazakh \\
ethnopedagogy: methods, \\
principles of research; \\
• Kazakh ethnopedagogy \\
relationship with folk pedagogy \\
and social pedagogy; \\
- revealing structural and \\
component composition \\
Kazakh ethnopedagogy; \\
- revealing the methodological \\
characterictics; \\
-framework of program and \\
procedure of research.
\end{tabular} & \begin{tabular}{|l}
$\bullet$ - identification "knowledge about knowledge" of the \\
Kazakh ethnopedagogy \\
$\bullet$ place of Kazakh ethnopedagogy in the pedagogical \\
sciences \\
$\bullet$ - studying the specifics of the Kazakh ethnic upbringing; \\
- studying the conceptual and terminological system of \\
Kazakh ethnopedagogy; \\
$\bullet$ revealing the essence of the ethno-social and role- \\
based approach in upbringing; \\
- study formation features of the national character, self- \\
consciousness.
\end{tabular} & \begin{tabular}{|l}
- upbringing the ethnic group as holistic entity \\
bio-social system; \\
• formation of ethnic consciousness, spirituality \\
and worldview as the basis of Kazakh mentality; \\
• upbringing in children a sense of patriotism, \\
sincere devotion and love for his people and the \\
Motherland; \\
• inculcating the love of mother tongue, national \\
culture and history, customs and traditions, \\
material and spiritual values of national culture \\
• introduction to ethno-ethical norms and \\
ethnosocial roles; \\
- upbringing friendly relations to all nations, the \\
expansion of knowledge about them and their \\
culture.
\end{tabular} \\
\hline \multirow[t]{2}{*}{ Object } & \multicolumn{3}{|c|}{ developing ethnopedagogical validity } \\
\hline & \begin{tabular}{||l} 
Ethnopedagogy. \\
Ethnopedagogical researches.
\end{tabular} & $\begin{array}{l}\text { national and traditional-consumed culture. } \\
\text { ethnopedagogical culture. }\end{array}$ & $\begin{array}{l}\text { ethnopedagogical culture of the Kazakh people. } \\
\text { ethnopedagogical process of school and family. }\end{array}$ \\
\hline Subject & $\begin{array}{l}\text { state reflection of the real } \\
\text { ethnopedagogical reality in } \\
\text { ethnopedagogical studies }\end{array}$ & $\begin{array}{l}\text { Kazakh ethnic education as holistic a continuous process, } \\
\text { carried out over a lifetime... in the course of which, the } \\
\text { person is the subject of developing ethnic group, acquires } \\
\text { ethnic values and the role of ethno-social, ethnic norms } \\
\text { laid down in the customs and traditions of his people, as a } \\
\text { result of which ethnic identity is formed, an adequate } \\
\text { attitude to her as a member of the ethnic group, a sense } \\
\text { of pride in their nation, a positive attitude to the language, } \\
\text { history and culture of their ethnic group, as well as a } \\
\text { sense of respect and tolerance towards people of other } \\
\text { ethnic groups. }\end{array}$ & $\begin{array}{l}\text { • the basic requirements of the Kazakhs to } \\
\text { children upbringing; } \\
\text { •peculiarities of girls upbringing and boys } \\
\text { upbringing; } \\
\text { • Kazakh national etiquette; } \\
\text { • ancestry, norms of family relations; } \\
\text { - system of customs and traditions as a means } \\
\text { of ethnic upbringing; } \\
\text { - meaning of concepts «қара шаңырақ», } \\
\text { «отау» in the Kazakh family ethnо-реdagogy, } \\
\text { «тннғыш ұл," «кенже ұл," «жалғыз ұл»; } \\
\text { • реculiarity roles of «ата," «әже» in the Kazakh } \\
\text { ethno-pedagogy, their multiple meaning and } \\
\text { multifunctionality (ақсақал, қария, кейуана, } \\
\text { aна); } \\
\text { •laws of obedience in the Kazakh etno- } \\
\text { pedagogy; } \\
\text { • prohibitions (taboos), blessing and curse. }\end{array}$ \\
\hline Functions & \begin{tabular}{|l} 
- cognitive (research); \\
- critical (estimated); \\
- reflexive, the study their own \\
status; \\
- development of methods for \\
the study of the Kazakh \\
ethnopedagogy based on the \\
study of research methods in
\end{tabular} & $\begin{array}{l}- \text { cognitive; } \\
\text { - Description (what is?), the classification by themes, } \\
\text { classification by levels; } \\
\text { - praxiological (how to achieve this or that result?) } \\
\text { - axiological (what and how should it be?) } \\
\text { - study progressive tradition essence of Kazakh people; } \\
\text { - cognition of the essence upbringing laws of ancestors } \\
\text { (family tree) (шежipe); }\end{array}$ & \begin{tabular}{|l} 
functions of society in ethnic upbringing of \\
children: lectures, special TV programs, contests \\
"Қыз сыны," "Жiгiт сұлтаны," the healthy \\
lifestyle promotions of famous people, the true \\
patriots, warriors, biys Khans, scientists, \\
governmental figures, art and literature. \\
function of the school: using materials of Kazakh \\
ethnopedagogy in the educational-upbringing
\end{tabular} \\
\hline
\end{tabular}




\begin{tabular}{|c|c|c|c|}
\hline & \begin{tabular}{|l} 
ethnology, ethno-psychology, \\
ethnic sociology, pedagogy; \\
- development of methods for \\
comparative studies of the \\
Kazakh ethnopedagogy and \\
other nations; \\
• development of methods for \\
the study of integrative \\
disciplines; \\
• development of research \\
instruments Interscience, \\
interdisciplinary, indisciplinary \\
connections of \\
ethnopedagogy; \\
• development selection \\
criteria of methodological \\
knowledge in ethnopedagogy \\
and etc.
\end{tabular} & $\begin{array}{l}\text { - formation of a national worldview; } \\
\text { - formation of the national mentality; } \\
\text { - upbringing on the values of the national culture of the } \\
\text { people; } \\
\text { - cultivation of patriotism, love for language, history; } \\
\text { - promotion of positive experiences of ethnic upbringing: } \\
\text { schools, families; } \\
\text { - preserve the identity of the Kazakh people through } \\
\text { aesthetic upbringing in the system of continuing } \\
\text { education. }\end{array}$ & \begin{tabular}{|l} 
process of school: through special subject \\
"әдеп"; through academic subjects in \\
accordance with the theme, through clubs, \\
centers and etc. \\
methodological support: programs, manuals, \\
methodical recommendations, concepts, etc. \\
functions of the family: the implementation \\
requirements of the Kazakh ethnopedagogy in \\
the family, the development and implementation \\
of ethnic and social roles in accordance with the \\
norms of the Kazakh national etiquette, \\
upbringing on progressive traditions of its \\
people.
\end{tabular} \\
\hline Methods & \multicolumn{2}{|c|}{\begin{tabular}{|l} 
general scientific methods of analysis, synthesis, deduction, induction, analogy, \\
idealization, comparison, observation, experiment, measurement, modeling and etc. \\
interdisciplinary approaches: a systematic, integrated, holistic, ethnopedagogical, cultural, \\
sociological, ethnographical.
\end{tabular}} & $\begin{array}{l}\text { methods and techniques of the Kazakh ethnic } \\
\text { upbringing: an explanation, persuasion, } \\
\text { inurement, learning, Example-sample, advice, } \\
\text { admonition, request, suggestion. approval, } \\
\text { praise, gratitude, hint prohibition, conviction, } \\
\text { involvement in a responsible and interesting } \\
\text { activity, the manifestation of grief, irony, } \\
\text { discontent, orders, gentle reproach, blessing - a } \\
\text { kind parting wishes, promotion, punishment, } \\
\text { incantation, a curse (терic бата берy), etc. } \\
\end{array}$ \\
\hline Principles & \multicolumn{2}{|c|}{$\begin{array}{l}\text { principles of objectivity, intelligibility; determinism; development of historicism, the unity of } \\
\text { theory and practice; cumulativity; unity of history and logic, complexity, integrity, } \\
\text { systematicity; aspect purity and certainty of subject, excluding special; ethnic and social } \\
\text { relations, the unity of biological and social anthropologism; nationality (ethnicity); cultural } \\
\text { congruity; natural congruity, excluding age and individual characteristics. }\end{array}$} & \begin{tabular}{|l} 
Principles of Kazakh ethnical upbringing: record \\
of age peculiarities, record of individual \\
peculiarities, cultural congruity, natural congruity, \\
sex-role orientation, anthropologism, priority \\
familial relationship, the principle of respecting \\
the elders.
\end{tabular} \\
\hline Laws & \begin{tabular}{|l}
$\mid$ aws of materialist dialectics: \\
negation and the transition to a \\
quantitative in quality, unity \\
and struggle of opposites. \\
categories of materialist \\
dialectics: the phenomenon \\
and the essence, form and \\
content, chance and necessity, \\
space and time, part and \\
whole, the quality and the \\
property, the individual and the \\
general. \\
Anthropologism philosophy as \\
the basis wт the cognition of \\
the ethnopedagogy laws. \\
\end{tabular} & \begin{tabular}{|l||}
-laws of general pedagogy; \\
$\bullet$ - Laws of upbringing real life; \\
- moral and ethical laws in the ethnic culture of Kazakh \\
people; \\
- basis of ethno-pedagogical laws; \\
- system upbringing traditions, moral and ethical \\
prohibitions as a manifestation of the ethnopedagogy laws \\
- ethnic social roles as the basis of the laws \\
ethnopedagogy.
\end{tabular} & \begin{tabular}{|l} 
- Law "Zheti ata" - knowledge of the family tree \\
to 7 of the knee and a ban on marriages of \\
relatives between relatives up to 7 knee; \\
- civil rights law; \\
- levirate law \\
- shariah law; \\
- system of customs and traditions; \\
- ethnic social roles as a system of norms and \\
moral and ethical attitudes.
\end{tabular} \\
\hline \multirow[t]{2}{*}{ Regularities } & \multicolumn{2}{|l|}{ Pedagogical regularities } & \multirow[t]{2}{*}{$\begin{array}{l}\text { •ұяда не көрсең, ұшарда соны ілерсің; } \\
\text { •шешесін көріп, қызын ал, ыдысын көріп } \\
\text { асын іш; } \\
\text { • әкеңе не істесең, алдыңа сол келер; } \\
\text { •и т. д. }\end{array}$} \\
\hline & \begin{tabular}{|l} 
philosophical principle of \\
determinism, chance and \\
necessity, possibility and \\
reality.
\end{tabular} & Regularities of general pedagogy & \\
\hline Theories & $\begin{array}{l}\text { theoretical and methodological } \\
\text { foundations of Kazakh } \\
\text { ethnopedagogics (K. Zh. } \\
\text { Kozhakhmetova). }\end{array}$ & \multicolumn{2}{|c|}{$\begin{array}{l}\text { I. problems of aesthetic upbringing in Kazakh folk pedagogy: S. A. Uzakbayeva, R. K. Dyusembinova, B. A. } \\
\text { Almukhambetova, A.K. Assanova, T. A. Kishkashbayev, S. A. Zholdasbekova and etc } \\
\text { II. problems of moral, labor, physical upbringing of schoolchildren by means of Kazakh folk pedagogy:A. E. } \\
\text { Dairabayeva, Zh. Sakenov, O.A. Satkanov, A.K. Kisymova, Zh. B. Sadyrmekova, R.K. Toleubekova, B. A. } \\
\text { Toylybayev, S. Imanbayeva and etc. } \\
\text { III. scientific and pedagogical foundations of public education and ways to implement the ideas of folk } \\
\text { pedagogy in the educational-upbringing process: S.K. Kaliev, T. Konyratbayeva, A. Ashaiuly, S. } \\
\text { Zhamansarieva and etc. }\end{array}$} \\
\hline
\end{tabular}




\begin{tabular}{|c|c|c|c|}
\hline & & \multicolumn{2}{|c|}{$\begin{array}{l}\text { IV. problems of upbringing and education process in the pre-school institutions of the country:A.S. Amirova, } \\
\text { T. Imanbekov, T.A. Levchenko. } \\
\text { V. problems of preparing future teachers: T.Sh. Kuanyshev, A.S. Magauova, K.K. Bulatbayev, Zh. S. } \\
\text { Khasanov, U. M. Abdigapparova, B. Zh. Mukanova and etc. } \\
\text { VI. problems of musical and aesthetic education of schoolchildren by means of Kazakh traditional and art } \\
\text { culture: M. Kh. Baltabayev, E. Kozybayev. } \\
\text { VII. ethno-cultural education of schoolchildren: Zh. Zh. Nauryzbay. } \\
\text { VIII. ethnopedagogical education of high school students: S.A. Uzakbayeva, K. Zh. Kozhakhmetova. }\end{array}$} \\
\hline $\begin{array}{l}\text { Sources of } \\
\text { Kazakh } \\
\text { ethno- } \\
\text { pedagogy }\end{array}$ & \begin{tabular}{|l} 
- heritage of the Kazakh \\
thinkers zhyrshy-zhyrau, \\
philosophers, writers, akyns \\
about pedagogical culture of \\
kazakh people; \\
- Classification of Kazakh oral \\
literature: A. Baitursynov M. \\
Auezov, S. Sefullin, B. \\
Kenzhebayeva, B. Uakatova, \\
S. Kaskabasova, Kh. \\
Dosmukhamedov; \\
- works of scientists ethno- \\
philosophers ethno- \\
culturologists, ethnopedagogy, \\
historians, anthropologists, \\
ethno-psychologists \\
\end{tabular} & $\begin{array}{l}\text { research on the history of educational thought } \\
\text { development in Kazakhstan:K. B. Zharykbayev, S. K. } \\
\text { Kalyev, G. M. Khrapchenkov, K. K. Kunantayeva, A. N. } \\
\text { lliasova, A. Kubesov, G. Sh. Shaimerdenova, Sh. } \\
\text { Zhumatayeva, Kh. Shalgynbayeva, A. M. Kudiarova, R. } \\
\text { Koshenova, A. Tursunova, Kokkozova and others. }\end{array}$ & $\begin{array}{l}\text { materials of oral national creativity, decorative } \\
\text { and applied arts, in rare funds of libraries, } \\
\text { ethnographic museums; monuments of } \\
\text { architecture, art; experience of school works, } \\
\text { cultural centers. }\end{array}$ \\
\hline \multirow[t]{7}{*}{\begin{tabular}{|l} 
Concepts \\
terms \\
categories
\end{tabular}} & | & \multicolumn{2}{|c|}{$\begin{array}{l}\text { ethnonym; ethnic consciousness; ethnic stereotype; the ethnonational; tradition, custom, ethnogenesis, } \\
\text { ethnicity, language, religion, ethnos, people, ethnic group, nation, subethnos; genus, tribe; endogamous; } \\
\text { ethnic identity }\end{array}$} \\
\hline & \begin{tabular}{|l} 
borrowed from \\
Kazakh \\
philosophy
\end{tabular} & \multicolumn{2}{|c|}{$\begin{array}{l}\text { ethnic World View, ethnic mentality, beliefs, signs, bans; concepts about space and time, veneration of } \\
\text { ancestors, religious beliefs, folk astronomy, folk calendar, traditional medicine, folk metrology perception of } \\
\text { the world, understanding of the world. }\end{array}$} \\
\hline & \begin{tabular}{|l|l|} 
borrowed from \\
ethnopsychology
\end{tabular} & \multicolumn{2}{|c|}{$\begin{array}{l}\text { national psychology, ethnic psychology, mental store, national feeling, national character, national identity, } \\
\text { national interest, customs, traditions, rites, ritual, ceremony. }\end{array}$} \\
\hline & \begin{tabular}{|l} 
borrowed from \\
theories of \\
culture
\end{tabular} & \multicolumn{2}{|c|}{$\begin{array}{l}\text { ethnopedagogical culture, traditional culture, ethnic culture, national culture, material culture, spiritual } \\
\text { culture; socionormative culture, folk culture, traditional culture, folk pedagogical culture, traditional artistic } \\
\text { culture, culture of family relationships. }\end{array}$} \\
\hline & \begin{tabular}{|l} 
borrowed from \\
general pedagogy
\end{tabular} & \multicolumn{2}{|c|}{$\begin{array}{l}\text { upbringing, formation, development, heredity, continuity, environment;, socialization, methodology, } \\
\text { methodological knowledge. }\end{array}$} \\
\hline & \begin{tabular}{||l} 
Categories of \\
Kazakh \\
ethnopedagogy
\end{tabular} & \multicolumn{2}{|c|}{$\begin{array}{l}\text { ethnopedagogy: the national pedagogy; Kazakh ethnopedagogy, folk pedagogy, ethnic upbringing, national } \\
\text { upbringing, folk education; ethno-ethics; ethno-science, ethnomethodology, ethno-cultural education. }\end{array}$} \\
\hline & \begin{tabular}{|l} 
Concepts of \\
Kazakh \\
ethnopedagogy
\end{tabular} & \multicolumn{2}{|c|}{$\begin{array}{l}\text { upbringing customs, upbringing traditions, rituals upbringing, educational rituals, beliefs, subjects; } \\
\text { Ethnopedagogical knowledge; ethnosocial role, learning, ethnic consciousness, ethnicization, bans (taboo), } \\
\text { Blessing (bata), norms of relative relations, national school, a national educational system of the school }\end{array}$} \\
\hline
\end{tabular}

A developed, structured, and logical model of the Kazakh ethnopedagogy is universal and can be used as a basis for studying and developed of ethnic pedagogy of any ethnic community.

\section{Summary and Conclusions}

In connection with obtaining sovereignty former Soviet republics, including Kazakhstan, actualized research on ethnopedagogy. Moreover, the emphasis is moved exactly toward the study of ethnic aspect of the problem, because "at present is of particular relevance to overcome without the national character of the so-called international consciousness and behavior" (G.N. Volkov). Researchers began to penetrate more deeply into the essence of the concepts of "folk" and "national," while explaining that "the ethnopedagogy associated with a particular ethnic background" (M. I. Stelmakhovich).

However, the analysis shows that not all the authors are demarcated ethnic and social aspects of problems often is the identification of "national" and "national." All this confirms the correctness of our approach to the study of ethnicity theory as content-Kazakh ethnopedagogy terminological basis, for ethnic pedagogy itself has roots in ethnography, the subject of which is the theory of the ethnic group.

The studied problem has a great perspective, because it is demanded by the natural life of the people, therefore, it 
is eternal. Our attempt to develop a methodological bases of the Kazakh ethnopedagogy has shown that ripened necessity to develop research in the following line, which allows go deep into the essence of relationships: ethnopedagogy and ethnic psychology, and ethnopedagogy ethnoculturology, ethnopedagogy and philosophy and pedagogy ethnopedagogy, ethnopedagogy and social pedagogy. Development of methodological bases highlighted the need for research into the problems of Kazakh mentality in the aspect of the relationship ethnopedagogy, ethnopsychology, ethno-philosophy.

\section{References}

Lordkipanidze D. O., 1954. Pedagogical teaching of K. D. Ushinsky. - M.: 1954. -368 p.

Volkov G. N., 1974. Ethnopedagogy. - Cheboksary: Chuvashia book edition, 1974. - (276) 376 p.

Ushinsky K. D., 1988. About nationalities in the public education. Pedagogical composition. In 6 valumes. / composed S. F. Egorov. M.: Pedagogy, 1988. - v. 1. p. 194-256.

Afanasev V.G., 1981 Community: consistency, cognition and management. - M.: Politizdat, 1981. - 432 p.

Sadovsky V.I., 1983. The formation of general systems theory. - M. Politizdat, 1983. $-253 \mathrm{p}$.

Kantor I. M., 1980. Conceptual and terminological system of pedagogy: The logical and methodological problems. Preface corresponding member of the Academy of Pedagogical Sciences of the USSR M.N.Skatkina.-M.: Pedagogy, 1980.-152 p.

Kedrov B. M., 1985. Classification of Sciences. Prediction of K. Marx about future science. - M., 1985.

Kozhakhmetova K. Zh., 1998. Kazakh ethno-pedagogy: methodology, theory, practice. - Almaty.: Science, 1998. - 317 p. 